\title{
Pemetaan Kecamatan - Kecamatan di Kabupaten Bolaang Mongondow Berdasarkan Hasil Produksi Pertanian dan Perkebunan Dengan Menggunakkan Analisis Biplot
}

\author{
${ }^{1}$ Friscilia D Kahuweka, ${ }^{2}$ Marline Paendong, ${ }^{3}$ Yohanes Langi \\ ${ }^{1}$ Program Studi Matematika, F-MIPA, UNSRAT,frisciliakahuweka@gmail.com \\ ${ }^{2}$ Program Studi Matematika, F-MIPA, UNSRAT,marline paendong@yahoo.com \\ ${ }^{3}$ Program Studi Matematika, F-MIPA, UNSRAT,yarlangi@gmail.co.id
}

\begin{abstract}
Abstrak
Pertanian adalah suatu kegiatan manusia yang termasuk didalamnya yaitu bercocok tanam, peternakan, perikanan dan juga kehutanan. Sebagian besar mata pencaharian masyarakat di negeri Indonesia adalah sebagai petani, sehingga sektor pertanian sangat penting untuk dikembangkan di negara kita.Tujuanpenelitianiniadalahmemetakkan secara grafis antara kecamatan-kecamatan di Kabupaten Bolaang Mongondow berdasarkan hasil produksi pertanian dan perkebunan dengan menggunakkan Analisis Biplot.Data yang digunakan dalam penelitian adalah data sekunder tentang banyaknya hasil produksi pertanian dan perkebunan di Kabupaten Bolaang Mongondow tahun 2012.Hasilnyamenunjukkanbahwakecamatan-kecamatantelah memiliki hasil produksi pertanian dan perkebunan yang unggul adalah kecamatan Dumoga Barat, kecamatan Dumoga Utara, kecamatan Dumoga Timur, Lolayan, kecamatan Passi Timur, kecamatan Passi Barat, kecamatan Bilalang, dan kecamatan Lolak. Sedangkan objek-objek yang belum unggul adalah kecamatan Poigar, kecamatan Bolaang, kecamatan Bolaang Timur, dan kecamatan Sang Tombolang.
\end{abstract}

Kata kunci :AnalisisBiplot, ProduksiPertaniandan Perkebunan

\section{Mapping the Sub-Districts in BolaangMongondow based Agriculture and Horticulture Production using Biplot Analysis}

\begin{abstract}
Agriculture is an human activity which includes farming, animal husbandry, fisheries and forestry. Most of the people's live lihood in the country Indonesia is a farmer. The purpose of this study is graphically mapping between sub-districts in BolaangMongondow based agricultural production and plantation using Biplot Analysis. The data used in this study are secondary data on the number of agricultural production and plantations in BolaangMongondowin 2012. Results showed that the sub-districts that al ready have superior production agriculture and plantation are DumogaWest districts, North Dumoga districts, East Dumoga districts, Lolayan, East Passi districts, West Passi districts, Bilalang districts, and Lolak districts. While sub-districts are not superior are Poigar districts, Bolaang districts, East Bolaang districts, and Tombolang districts.
\end{abstract}

Keywords :BiplotAnalysis, AgricultureProductionandPlantation

\section{Pendahuluan}

Alam Indonesia yang subur menjadi salah satu faktor yang mendukung sektor pertanian menjadi unggul, yang memacu pertumbuhan ekonomi terutama di daerah-daerah yang masih mengandalkan sektor pertanian sebagai mata pencaharian penduduk didaerah tersebut. Sehingga pertanian merupakan salah satu keunggulan negara kita yang merupakan negara agraris. Secara umum pengertian dari pertanian adalah suatu kegiatan manusia yang termasuk didalamnya yaitu 
bercocok tanam, peternakan, perikanan dan juga kehutanan. Sebagian besar mata pencaharian masyarakat di negeri Indonesia adalah sebagai petani, sehingga sektor pertanian sangat penting untuk dikembangkan di negara kita. Hasil-hasil pertanian yang ada di Indonesia diantaranya tanaman pangan seperti padi, jagung, kacang kedelai, kacang tanah, kacang hijau, ubi jalar, ubi kayu, dan tanaman perdagangan seperti kopi, teh, kelapa, karet, kina, cengkeh, kapas, tembakau, kelapa sawit, dan juga tebu. Perkebunan adalah lahan usaha pertanian yang luas, biasanya terletak di daerah tropis, yang digunakan untuk menghasilkan komoditi pertanian yang di perdagangkan dalam skalar besar dan di pasarkan ke tempat yang jauh, bukan untuk di konsumsi lokal.

Kabupaten Bolaang Mongondow adalah salah satu kabupaten yang ada di Sulawesi utara Indonesia, pada umumnya mata pencaharian masyarakat di daerah ini sebagai petani yang memanfaatkan sektor pertanian dan perkebunan yang ada di daerah mereka. Beberapa hasil produksi pertanian dan perkebunan yang ada di kabupaten Bolaang Mongondow diantaranya adalah kelapa, kopi, pala, jambu mete, kakao, vanili, lada, padi, ubi kayu, ubi jalar, kacang tanah, kacang hijau, kacang kedelai, dan lain-lain. Hasil produksi pertanian dan perkebunan menentukan peningkatan ekonomi daerah tersebut. Jika produksi pertanian gagal maka pemasaran pun menurun, begitupun dengan tingkat ekonominya juga menurun.

Analisisbiplotbersifatdeskriptifdengandimensidua yang dapat menyajikan secarasimultan objek dan variable dalam satu grafik. Grafik yang di hasilkan dari Biplot ini merupakan grafik yang berbentuk bidang datar. Dengan penyajian seperti ini, ciri-ciri variable dan objek pengamatan serta posisi relative antara objek pengamatan dengan variable dapat dianalisis.

Analisis Biplot adalah salah satu upaya menggambarkan data-data yang ada pada tabel ringkasan dalam grafik berdimensi dua. Biplot ini pertama kali diperkenalkan oleh Gabriel (1971) dan telah diperbaharui oleh Gower dan Hand (1996). Baris menunjukkan sampelatau unit sampel, sedangkan kolom menunjukkan variabel. Analisis ini digunakan untuk menggambarkan baris dan kolom yang terdapat dalam matriks dalam grafik tunggal. Nilai-nilai yang terdapat dalam matriks ini diperoleh dari penguraian nilai singular dari matriks awal. Analisis ini telah digunakan untuk menggambarkan hubungan antara objek dan variable dalam grafik tunggal.

\section{AnalisisBiplot}

Analisis biplot didasarkan pada penguraian nilai singular suatu matriks (Singular Value Decompotion, SVD). Penguraian nilai singular dari suatu matriks merupakan teorema dasar banyak digunakan dalam perhitungan matriks. Biplot diperkenalkan oleh Gabriel tahun 1971 yang mengembangkan metode biplot sebagai suatu alat analisis data yang dapat meringkas informasi dari suatu matriks data yang besar, dan telah diperbaharui oleh Gower dan Hand pada tahun 1996 [4].

Analisis biplot adalah teknik statistika deskriptif yang dapat disajikan secara visual guna menyajikan secara simultan $\mathrm{n}$ objek pengamatan dan $\mathrm{p}$ peubah da lam ruang bidang datar, sehingga ciri-ciri peubah dan objek pengamatan serta posisi relatif antar objek pengamatan dengan peubah dapat dianalisis [2].

Misalkan suatu matriks data $X$ berukuran ( $n x p)$ yang berisi $n$ pengamatan dan $p$ peubah yang dikoreksi terhadap nilai rata-ratanya dan berpangkat $r$, maka penguraian nilai singular (SVD) suatu matriks ${ }_{n} X_{p}$ selalu dapat ditulis dalam bentuk sebagai berikut :

$$
X=U L A^{\prime}
$$

dengan matriks $U$ dan A masing-masing berukuran $\left(\begin{array}{lll}n & x & r\end{array}\right)$ dan $\left(\begin{array}{l}p \\ x\end{array} r\right)$ sehingga $U^{\prime} U=A^{\prime} A=I$. Jika $\lambda_{\mathrm{i}}$ adalahakarciridarimatriks $X^{\prime} X$, maka $L$ adalah matriks diagonal berukuran $\left(\begin{array}{lll}r & x & r\end{array}\right)$ dengan unsur-unsur diagonal adalah akar kuadrat dari akar ciri $X^{\prime} X$ sehingga $\sqrt{\lambda_{1}} \geq \sqrt{\lambda_{2}} \geq \cdots \geq \sqrt{\lambda_{r}}$. Unsur-unsur diagonal dari matriks $L$ disebut nilai matriks singular matriks $X$. Kolomkolommatriks $U$ terdiridarirvektorc iridarimatriks $X^{\prime} X$. Kolom-kolommatriks $U$ disebut vektor singular kolommatriks $X$ dalamruangberdimensin. kolom-kolommatriks Aterdiridarirvektor ciridarimatriks $X$ 'Xyang berpadanandenganakarciri $\lambda$. Dengan penjabaran persamaan (1): 


$$
X=U L A^{\prime}=U L^{\propto} L^{1-\propto} A^{\prime}
$$

dengan pendefinisian $G=U L^{\alpha}$ dan $H=A L^{1-\alpha}$, hal ini berarti unsur ke-(i,j) maka persamaan (2)dapat dituliskan sebagai berikut :

$$
X_{i j}=g_{i}^{\prime} h_{j}
$$

dimana : $\quad i=1,2,3, \ldots, n$

$j=1,2,3, \ldots, p$

Nilai skalar $\alpha$ yang muncul dalam pendefinisian $\mathrm{G}$ dan $H^{\prime}$ dapat dinilai sembarang, tetapi pengambilan nilai ekstrim untuk $\alpha=0$ dan $\alpha=1$ akan berguna dalam interpretasi biplot. Jika $\alpha=0$ maka $\mathrm{G}=\mathrm{U}$ dan $\mathrm{H}=\mathrm{AL}$ sehingga jarak euclid antara $g_{h}$ dan $g_{i}$ akan sama dengan jarak euclid $x_{h}$ dan $x_{i}[2]$.

Terdapat empat hal penting yang bisa diperoleh dari tampilan Analisis Biplot, yaitu :

1. Hubungan (korelasi) antar peubah, dengan menggunakan biplot peubah akan digambarkan sebagai garis berarah. Dua peubah yang memiliki korelasi positif tinggi akan digambarkan sebagai dua buah garis dengan arah yang sama, atau membentuk sudut yang sempit. Apabila dua peubah yang memiliki korelasi negatif tinggi akan digambarkan dalam bentuk dua garis yang arahnya berlawanan, atau membentuk sudut yang lebar (tumpul). Sedangkan dua buah peubah yang tidak berkorelasi akan digambarkan dalam bentuk dua garis yang mendekati $90^{\circ}$ (siku-siku)

2. Keragaman peubah, informasi ini digunakan untuk melihat apakah ada peubah tertentu yang nilainya hampir sama setiap objek ada yang sama besar dan ada juga yang sangat kecil. Dengan informasi ini, bisa diperkirakan pada peubah mana strategi tertentu harus ditingkatkan, serta sebaliknya. Dalam biplot, peubah dengan keragaman kecil digambarkan dengan vektor yang pendek, sedangkan peubah yang ragamnya besar digambarkan sebagai vektor yang panjang.

3. Kedekatan antar objek, informasi ini bisa dijadikan panduan objek mana yang memiliki kemiripan karakteristik dengan objek tertentu. Dalam biplot, dua objek dengan karakteristik sama akan digambarkan sebagai dua titik yang posisinya berdekatan.

4. Nilai peubah pada suatu objek, informasi ini digunakan untuk melihat keunggulan dari setiap objek. Objek yang terletak searah dengan arah dari suatu peubah dikatakan bahwa pada objek tersebut nilainya diatas rata-rata. Sebaliknya jika objek la in terletak berlawanan dengan arah dari peubah tersebut maka objek tersebut memiliki nilai dekat dengan ratarata [3].

\section{MetodologiPenelitian}

Data yang digunakan dalam penelitian adalah data sekunder tentang banyaknya hasil produksi pertanian dan perkebunan di Kabupaten Bolaang Mongondow tahun 2012. Data tersebut diperoleh dari Badan Pusat Statistik (BPS) provinsi Sulawesi Utara.

\subsection{WaktudanTempatPenelitian}

Penelitian ini dilakukan mulai pada tanggal 1 April - 30 April 2014 dan penelitian ini dilakukan di Badan Pusat Statisika provinsi Sulawesi Utara Manado.

\subsection{VariabeIPenelitian}

\subsubsection{ObjekPenelitian}

Objek penelitian adalah kecamatan-kecamatan yang ada di Kabupaten Bolaang Mongondow yang disajikan pada tabel 1 . 
Tabel 1. Objek Pene litian

\begin{tabular}{|l|l|}
\hline No & NamaKecamatan \\
\hline 1 & Dumoga Barat \\
\hline 2 & Dumoga Utara \\
\hline 3 & DumogaTimur \\
\hline 4 & Lolayan \\
\hline 5 & Passi Barat \\
\hline 6 & PassiTimur \\
\hline 7 & Bilalang \\
\hline 8 & Poigar \\
\hline 9 & Bolaang \\
\hline 10 & BolaangTimur \\
\hline 11 & Lolak \\
\hline 12 & Sang Tombolang \\
\hline
\end{tabular}

\subsubsection{Peubah yang diamati}

Peubah-peubah yang diamati adalah peubah hasil produksi pertanian danperkebunan yang ada di Kabupaten Bolaang Mongondow. Peubah-peubah yang diamati disajikan pada tabel2.

Tabel 2. Peubah produksi pertanian dan perkebunan dalam ton

\begin{tabular}{|l|ll|}
\hline Peubah & HasilProduksiPertanian \\
\hline$X_{1}$ & ProduksiPadiSawah $\quad$ (ton) \\
\hline$X_{2}$ & ProduksiPadiLadang $\quad$ (ton) \\
\hline$X_{3}$ & produksiJagung & (ton) \\
\hline$X_{4}$ & ProduksiKedelai $\quad$ (ton) \\
\hline$X_{5}$ & ProduksiKacang Tanah (ton) \\
\hline$X_{6}$ & ProduksiUbiKayu $\quad$ (ton) \\
\hline$X_{7}$ & \multicolumn{2}{|l|}{ ProduksiUbiJalar $\quad$ (ton) } \\
\hline
\end{tabular}

\begin{tabular}{|l|ll|}
\hline$X_{8}$ & ProduksiKelapa & (ton) \\
\hline$X_{9}$ & Produksi Pala & (ton) \\
\hline$X_{10}$ & Produksi Kopi & (ton) \\
\hline$X_{11}$ & ProduksiKakao & (ton) \\
\hline$X_{12}$ & ProduksiKayuManis & (ton) \\
\hline$X_{13}$ & ProduksiLada & (ton) \\
\hline$X_{14}$ & ProduksiKemiri & (ton) \\
\hline$X_{15}$ & ProduksiAren & (ton) \\
\hline
\end{tabular}

\subsection{Analis is Data}

Metode analisis yang dilakukan dalam penelitian ini ada 2 tahap. Tahapan analisis yang dilakukan adalah sebagai berikut:

1. Data asal dianalisis dengan statistika deskriptif yang menggunakan perangkat lunak Microsoft

Excel. Hal ini dilakukan untuk mengetahui gambaran data secara umum. Dalam hal ini, 
yang digunakan sebagai variabel/peubah adalah hasil produksi pertanian dan perkebunan dalam ton, dan kecamatan-kecamatan sebagai objek pengamatan.

2.Dengan menggunakan analis is biplot dengan langkah-langkah sebagai berikut:

a. Melakukan pengumpulan data

b. Pemasukan data (matriks data X)

c. Standarisasi matriks X (Menggunakkan Minitab 14)

d. Penguraian matriks $X$ yang telah distandarisasi dengan SVD

e. Penghitungan matriks $\mathrm{H}=\mathrm{AL}$ dan $\mathrm{G}=\mathrm{UL}$

f. Plot matriks $\mathrm{G}$ dan $\mathrm{H}$ secara tumpang tindih.

Analisis biplot dilakukan dengan menggunakan makrodalam software SAS (Statistical Analysis System) versi 9.1.3.

\section{Hasil Dan Pembahasan}

\subsection{Plot antara peubah jumlah hasil produksi pertanian dan hasil perkebunan dengan objek pengamatan}

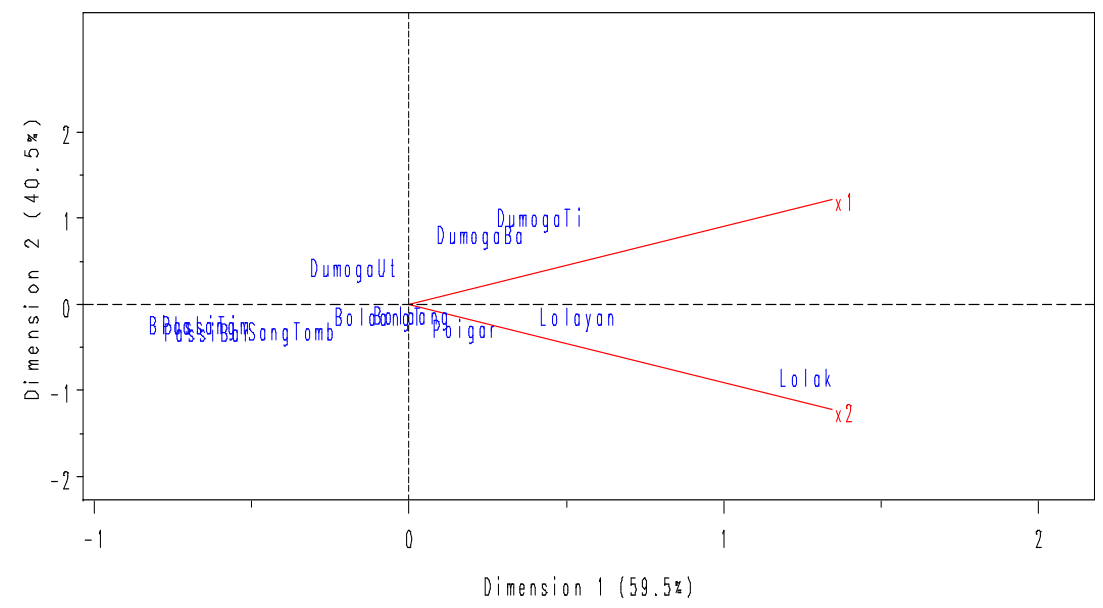

Gambar 1. Plot antara peubah (Jumlah hasil produksi pertanian dan hasil perkebunan) dengan objek pengamatan

Berdasarkan gambar 1, dapat dijelaskan bahwa kedekatan antar objek ditunjukkan oleh kecamatan Dumoga Barat, dan kecamatan Dumoga Timur karena jarak kedua objek yang berdekatan, sama halnya kedekatan antar objek ditunjukkan oleh kecamatanBila lang, Poigar, Lolayan, dan kecamatan Lolak karena jarak keempat objek yang berdekatan. Hal ini menunjukkan bahwa hasil produksi perkebunan keempat objek tersebut relatif sama. Sama halnya dengan kecamatan Passi Barat, Passi Timur, kecamatan Sang Tombolang, kecamatan Bolaang, dan kecamatan Bolaang Timur.

Keragaman yang diterangkan oleh dimensi 1 sebesar 59,5\% dan dimensi 2 sebesar 40,5\% sehingga total keragamannya sebesar $100 \%$. Hal ini berarti bahwa hasil produksi pertanian dan hasil produksi perkebunan sangat beragam. Gambar 16, menunjukkan bahwa ada beberapa objek yang terlihat jauh dari posisinya dan juga terletak tidak searah dengan vektor-vektor peubah yang ada. Hal ini berarti objekobjek tersebut memiliki hasil produksi pertanian dan hasil perkebunan yang belum unggul. Objek-objek tersebut diantaranya kecamatan Passi Barat, Passi Timur, kecamatan Sang Tombolang, kecamatan Bolaang, dan kecamatan Bolaang Timur. Sedangkan Bilalang, Poigar, Lolayan, kecamatan Lolak, kecamatan Dumoga Barat, dan kecamatan Dumoga Timur. Terletak dekat dan searah dengan vektor-vektor yang ada. Hal ini menunjukkan bahwa objek - objek tersebut memiliki hasil produksi 
pertanian dan hasil produksi perkebunan yang unggul di Kabupaten Bolaang Mongondow.

\subsection{Plot antara peubah hasil produksi pertanian dan perkebunan dengan objek pengamatan}

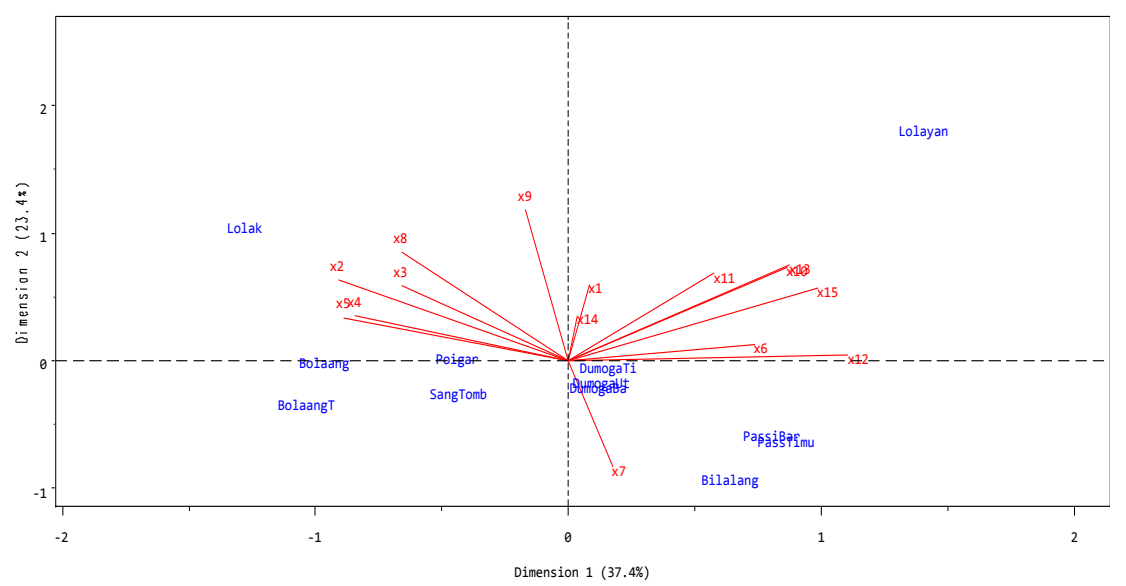

Gambar 2. Plot antarapeubah (Hasi lproduksi pertanian dan perkebunan) dengan objek pengamatan

Berdasarkan gambar 2, dapat dije laskan bahwa kedekatan antar objek ditunjukkan oleh kecamatan Dumoga Barat, kecamatan Dumoga Utara, dan kecamatan Dumoga Timur karena jarak ketiga objek yang berdekatan, sama halnya kedekatan antar objek ditunjukkan oleh kecamatan Passi Timur, kecamatan Passi Barat, dan kecamatan Bilalang karena jarak ketiga objek yang berdekatan. Hal ini menunjukkan bahwa hasil produksi ubi jalar keenam objek tersebut relatif sama. Sama halnya dengan kecamatan Poigar, kecamatan Sang Tombolang, kecamatan Bolaang, dan kecamatan Bolaang Timur.

Keragaman yang diterangkan oleh dimensi 1 sebesar 37,4\% dan dimensi 2 sebesar $23,4 \%$ sehingga total keragamannya sebesar $60,8 \%$. Rasio skala yang digunakan dalam biplot adalah 1.Keragaman peubah-peubah hasil produksi pertanian dan perkebunan di kabupaten Bolaang Mongondow antara lain produksi padi sawah $\left(\mathrm{X}_{1}\right)$, padi ladang $\left(\mathrm{X}_{2}\right)$, jagung $\left(\mathrm{X}_{3}\right)$, kedelai $\left(\mathrm{X}_{4}\right)$, kacang tanah $\left(\mathrm{X}_{5}\right)$,ubi kayu $\left(\mathrm{X}_{6}\right)$, ubi jalar $\left(\mathrm{X}_{7}\right)$, kelapa $\left(\mathrm{X}_{8}\right)$, pala $\left(\mathrm{X}_{9}\right)$, kopi $\left(\mathrm{X}_{10}\right)$, kakao $\left(\mathrm{X}_{11}\right)$, kayu manis $\left(\mathrm{X}_{12}\right)$, lada $\left(\mathrm{X}_{13}\right)$, kemiri $\left(\mathrm{X}_{14}\right)$, dan aren $\left(\mathrm{X}_{15}\right)$ yang dapat dilihat pada tabel asal.

Keragaman yang terbesar terjadi pada peubah Kayu Manis $\left(X_{12}\right)$, Aren $\left(X_{15}\right)$, lada $\left(\mathrm{X}_{13}\right)$, kopi $\left(\mathrm{X}_{10}\right)$, pala $\left(\mathrm{X}_{9}\right)$, kelapa $\left(\mathrm{X}_{8}\right)$, padi ladang $\left(\mathrm{X}_{2}\right)$, karena keenan peubah tersebut memiliki vektor yang paling panjang. Hal ini menunjukkan bahwa hasil produksi pertanian dan perkebunan di kabupaten Bolaang Mongondow sangat beragam. Keragaman terkecil terjadi pada peubah Kemiri $\left(\mathrm{X}_{14}\right)$ dan padi sawah $\left(\mathrm{X}_{1}\right)$, karena kedua peubah tersebut memiliki vektor yang paling pendek.

Korelasi positif terjadi pada peubah produksi kopi $\left(\mathrm{X}_{10}\right)$ dan peubah produksi lada $\left(\mathrm{X}_{13}\right)$ karena kedua peubah tersebut memiliki arah yang sama. Hal ini berarti bahwa semakin banyak hasil produksi kopi yang ada di kabupaten Bolaang Mongondow maka semakin banyak juga hasil produksi lada di kabupaten Bolaang Mongondow. Korelasi positif terjadi juga pada peubah produksi ubi kayu $\left(\mathrm{X}_{6}\right)$ dan peubah produksi kayu manis $\left(\mathrm{X}_{12}\right)$ karena kedua peubah tersebut memiliki arah yang sama. Hal ini berarti bahwa semakin banyak juga hasil produksi ubi kayu maka semakin banyak juga hasil produksi kayu manis yang ada di kabupaten Bolaang Mongondow. Korelasi positif juga, terjadi pada peubah produksi kemiri $\left(\mathrm{X}_{14}\right)$ dan peubah produksi padi sawah $\left(\mathrm{X}_{1}\right)$. Hal ini berarti semakin banyak hasil produksi kemiri, maka semakin banyak juga hasil produksi padi sawah yang dimiliki objek. Pada peubah produksi jagung $\left(\mathrm{X}_{3}\right)$ dan peubah produksi padi ladang $\left(\mathrm{X}_{2}\right)$ juga terjadi korelasi positif karena 
kedua peubah tersebut memiliki arah yang sama. Hal ini berarti bahwa semakin banyak hasil produksi jagung, maka semakin banyak juga hasil produksi padi ladang yang dimiliki objek pengamatan. Selain itu, korelasi positif juga terjadi pada peubah hasil produksi kedelai $\left(\mathrm{X}_{4}\right)$ dan peubah produksi kacang tanah $\left(\mathrm{X}_{5}\right)$. Hal ini berarti bahwa semakin banyak hasil produksi kedelai, maka semakin banyak juga hasil produksi kacang tanah yang dimiliki objek pengamatan.

Pada biplot terlihat bahwa kecamatan Lolayan unggul dalam produksi kopi $\left(\mathrm{X}_{10}\right)$, produksi kakao $\left(\mathrm{X}_{11}\right)$, produksi lada $\left(\mathrm{X}_{13}\right)$, dan produksi Aren $\left(\mathrm{X}_{15}\right)$ karena vektor dari peubah tersebut searah dengan objek kecamatan Lolayan. Selain itu dapat dilihat juga bahwa keunggulan kecamatan Lolak yaitu pada produksi padi ladang $\left(\mathrm{X}_{2}\right)$, produksi jagung $\left(\mathrm{X}_{3}\right)$, dan produksi ke lapa $\left(\mathrm{X}_{8}\right)$.

Gambar 2, juga menunjukkan bahwa ada beberapa objek yang terlihat jauh dari posisinya dan juga terletak tidak searah dengan vektor-vektor peubah yang ada. Hal ini berarti objek-objek tersebut memiliki hasil produksi yang belum unggul terhadap 15 hasil produksi pertanian dan perkebunan di kabupaten Bolaang Mongondow.Objek-objek tersebut diantaranya kecamatan Poigar, kecamatan Bolaang, kecamatan Bolaang Timur, dan kecamatan Sang Tombolang. Sedangkan kecamatan Dumoga Barat, kecamatan Dumoga Utara, kecamatan Dumoga Timur, Kecamatan Passi Barat, kecamatan Passi Timur, kecamatan Bilalang, kecamatan Lolayan, dan kecamatan Lolak. Terletak dekat dan searah dengan vektor-vektor yang ada. Hal ini menunjukkan bahwa objek - objek tersebut memiliki hasil produksi pertanian dan perkebunan yang unggul di Kabupaten Bolaang Mongondow.

\section{Kesimpulan}

Berdasarkan hasil analisa dan pembahasan, dapat disimpulkan bahwa :

1. Objek-objek yang dikategorikan telah memiliki hasil produksi pertanian yang unggul kecamatan Dumoga Timur unggul pada produksi padi sawah, kecamatan Bilalang unggul pada produksi ubi kayu, kecamatan Bolaang unggul pada produksi kedelai, kecamatan Bolaang Timur unggul pada produksi ubi jalar, dan kecamatan Lolak unggul pada produksi padi ladang, jagung, dan kacang tanah. Sedangkan objek-objek yang dikategorikan telah memiliki hasil produksi perkebunan yang unggul adalah kecamatan Lolayan unggul pada produksi pala, produksi kopi, produksi kakao, produksi kayu manis, produksi lada, produksi aren, dankecamatan Lolak unggul pada produksi kelapa, dan produksi kemiri.

2. Objek-objek yang dikategorikan telah memiliki hasil produksi pertanian dan perkebunan yang unggul di kabupaten Bolaang Mongondow adalah kecamatan Dumoga Barat, kecamatan Dumoga Utara, kecamatan Dumoga Timur, Lolayan, kecamatan Passi Timur, kecamatan Passi Barat, kecamatan Bilalang, dan kecamatan Lolak. Sedangkan objek-objek yang belum unggul adalah kecamatan Poigar, kecamatan Bolaang, kecamatan Bolaang Timur, dan kecamatan Sang Tombolang.

\section{DaftarPustaka}

[1] Everit, B. 1978. Graphical Techniques for Multivariate Data.Heinermann Educational Books.

[2] Jolliffe, I.T. 1986. Principal Component Analysis. Springer-Verlag. New York.

[3] Mattjik, A.A., M. Sumertajaya, H. Wijayanto, Indahwati, A. Kurnia, B. Sartono. 2004. Modul Teori Pelatihan Analisis Multivariat. Departemen Statistika FMIPA IPB. Bogor.

[4] Rencher, A.R. 2002. Methods Of Multivariate Analysis Second Edition. John Wiley \& Sons, Inc, New York. 